\title{
The Risk Premium Differential in Japanese-Era Taiwan and its Effect
}

\author{
by \\ KELLY B. OLDS *
}

\begin{abstract}
During the Japanese era, there was a lower risk premium in northern Taiwanese capital markets than in southern markets. Evidence suggests this was due to superior informal institutions in the north. As a result, northern property rights were better defined, northerners were less dependent on formal credit markets and landless farmers who had less access to formal markets were at a smaller disadvantage in the north than in the south. (JEL: N 2)
\end{abstract}

\section{Introduction}

The island of Taiwan is only 420 kilometers long measured north to south but before the Japanese built a modern transportation network in Taiwan, communication between the north and south of the island was difficult. The bulk of the population lived on the western coastal plain between the Taiwan Strait and the mountains. Streams and small rivers running from the mountains westward to the strait cut the island at many points. These streams are extremely variable in discharge volume and have wide rocky floodplains. Bridge building was often impractical. Foot trails were the primary means of travel and sixteen kilometers was probably the furthest one could travel in a day (HSU, PANNELL AND WHEELER [1980]). As a result, northsouth regional differences (the division line being the Chuo-shuei-hsi (濁水溪)) arose and persisted.

The south was generally the oldest settled region and, until the late nineteenth century, the seat of the island's government. It was also subject to more frequent feuding and rebellion (HSU [1980]). Geographers note that from earliest times nucleated settlements predominated in the south while settlements in the north consisted of dispersed individual houses (KNAPP [1999]). OLDS [2002] shows that net nutrition was lower in the south than in the north during the late nineteenth and early twentieth centuries. Southern adult males tended to be about 2 centimeters shorter

* I would like to thank Tsong-Min Wu, Ruey-Hua Liu, Hui-Wen Koo and participants at seminars at National Taiwan University, National Tsinghua University and National Chengchih University and Tunghai University for their comments and the NSC for funding. I would also like to thank Po-Chu U and Chia-Yi Chen for their assistance. 
than northern adult males. Japanese health surveys found the disease environment in the south worse than in the north (SANITATION OFFICE, INTERIOR BUREAU, TAIWAN GovERnMENT-GENERAL [1926]). To this day, the south of Taiwan is still noticeably poorer than the north although this regional disparity has received little scholarly attention.

Scholars such as A'HEARN [2000] and PUTNAM [1993] have argued that the underdevelopment of southern Italy stems at least in part from culture. Informal institutions allow northern Italians to cooperate better than southern Italians. The importance of informal institutions to economic development generally has been emphasized by DE SoTO [1989], GREIF [1994] and NoRTH [1990] among others. Such informal enforcement is often done in a sub-optimal manner (GREIF [1997]). In Ch'ing-dynasty Taiwan, contract enforcement was relatively informal (OLDS AND LIU [2000]) and informal enforcement remained important under Japanese rule, as it remains important today (WINN [1994]). The Taiwanese case, like the Italian case, shows that informal institutions can be important for development. North and south Taiwan have together shared a series of formal governments. But statistics compiled by the Japanese authorities on Taiwan clearly suggest that there was a larger risk premium in southern informal credit markets. Thus capital markets in the south were less efficient and southern capital was less likely to be used optimally. The difference in informal northern and southern interest rates persisted into the Kuomintang (KMT) period and thus affected Taiwan's post-war economic development.

Unfortunately, previous to this paper, there have been no comparative studies of lending institutions in northern and southern Taiwan during any period. The same means of borrowing money seem to have been available to people in both areas. Loans from friends, neighbors or relatives could be secured through a written contract, probably witnessed by one or more individuals, or through a temporary rotating credit association. Before the Japanese takeover in 1895, agents of the central government did not enforce such local contracts. The highest court of appeal in a dispute over a loan would be a panel of village elders meeting at the local temple. The central government neither selected nor funded village elders, but it allowed the locally selected elders to adjudicate such cases and impose a wide array of penalties based on their sense of what the village saw as fair (TAI [1979, pp. 152ff.]). The Japanese set up a formal system of courts to mediate such civil suits manned by Japanese personnel who interpreted customary Taiwanese law and applied Japanese law whenever possible and appropriate. Taiwanese responded by flooding the dockets with unsettled disputes indicating that they were not fully satisfied with the traditional means of dispute settlement (MOSER [1982, pp. 27ff.] and DAVIDSON [1903/1992, pp. 609f.]). The Japanese colonial government was thus cognizant of such disputes and, in theory, the disputes could work their way up to higher courts of appeal. The Japanese court system, however, had its own costs in time, money and the damage to important personal relationships. Taiwanese were often able to take care of loan disputes informally among themselves with lower costs. Presumably, the reputation and status of those who did not repay 
loans suffered, as it still does today. One of the outstanding features of the loan market in Taiwan is that the average Taiwanese could borrow at a lower rate of interest than the average Japanese living in Taiwan. This was in contrast to the situation in Korea where Japanese residents borrowed at cheaper rates than Koreans (TAX OfFice, Finance Bureau, TAiwan Government-General [1936, p. 78]).

Section two of this paper presents the evidence for a north-south interest rate differential in informal credit markets. Section three shows that the difference in interest rates was due to a risk premium or more generally transaction costs. It argues that the higher cost of borrowing had institutional causes. In the fourth section, the effects of the higher borrowing costs are described. The fifth section concludes.

\section{Interest Rates North and South}

The Japanese did five cross-sectional investigations into interest rates during their rule on Taiwan (1895-1945). Two of these studies were done in the first decade of the 20th century. Three later studies were done in the 1930s. All five studies show that interest rates were higher in the south.

The two earliest studies are poorly documented and are much less reliable than the later studies. The Provisional TAIWAN LAND Survey OfFICE [1906a] and [1906b] did the early studies as part of the land reform which created a registry of all Taiwanese landholdings (CH’ENG [1914/1963, pp. 63-69]). The two studies were issued in separate volumes: A Survey of Paddy Sale Prices and Interest Rates and A Survey of Dry Field Sale Prices and Interest Rates. These volumes each consist of one cross-sectional table showing estimated land values, returns to land, and interest rates for paddy and dry field respectively in each village in each of the 186 townships (堡 and 里) in the eighteen districts (㕔) stretching from Ilan to Hengch'un. Unfortunately, the volumes contain no information concerning how the information was gathered. The information in the volume dealing with paddy land is limited by the fact that some areas of the south had no irrigated paddy. There are also a small number of townships for which no interest rate estimates are recorded. In the report on dry fields, the interest rate reported is the interest rate when interest is paid in money. This is a nominal interest rate. In the report on paddy fields, the interest rate reported is the interest rate when interest is paid in rice. This approximates a real rate of interest. Table one shows the results the studies report. The real interest rate is shown to be $6 \%$ higher in the south while the nominal interest rate is $2.5 \%$ higher. During this early period, the table shows that interest rates were highest in the middle of the island (from Taichung to Chiayi) than in either the extreme north or south.

Three better-documented studies were done in the 1930s. The AGRICULTURE OFFICE, AGriculture AND INDUSTRY BUREAU, TAIWAN GOVERNMENT-GENERAL [1935], [1940] did two important surveys of rural credit markets as part of its Basic Agricultural Survey. The first was done in 1933 and the second in 1940. In the first 
Table 1

Annual Interest Rates and Returns to Holding Land, circa 1906

\begin{tabular}{|c|c|c|c|c|c|c|}
\hline $\begin{array}{l}\text { Name of } \\
T^{\prime} \text { ing }\end{array}$ & $\begin{array}{l}\text { Returns } \\
\text { to } \\
\text { holding } \\
\text { dry field }\end{array}$ & $\begin{array}{l}\text { Nominal } \\
\text { interest } \\
\text { rates }\end{array}$ & $\begin{array}{l}\text { Average } \\
\text { differen- } \\
\text { tial in } \\
\text { dry field } \\
\text { survey }\end{array}$ & $\begin{array}{l}\text { Returns } \\
\text { to } \\
\text { holding } \\
\text { paddy }\end{array}$ & $\begin{array}{l}\text { "Real" } \\
\text { interest } \\
\text { rates }\end{array}$ & $\begin{array}{l}\text { Average } \\
\text { differen- } \\
\text { tial in } \\
\text { paddy } \\
\text { survey }\end{array}$ \\
\hline Ilan & $12.1 \%$ & $15.0 \%$ & $2.9 \%$ & $12.2 \%$ & $15.4 \%$ & $3.2 \%$ \\
\hline Keelung & $12.9 \%$ & $14.0 \%$ & $1.1 \%$ & $8.9 \%$ & $10.2 \%$ & $1.3 \%$ \\
\hline Shenkeng & $11.7 \%$ & $14.8 \%$ & $3.1 \%$ & $8.9 \%$ & $11.5 \%$ & $2.6 \%$ \\
\hline Taipei & $8.2 \%$ & $13.6 \%$ & $5.4 \%$ & $8.3 \%$ & $10.2 \%$ & $1.9 \%$ \\
\hline Taoyuan & $12.2 \%$ & $14.9 \%$ & $2.7 \%$ & $9.0 \%$ & $12.8 \%$ & $3.8 \%$ \\
\hline Hsinchu & $11.5 \%$ & $14.6 \%$ & $3.1 \%$ & $10.8 \%$ & $13.4 \%$ & $2.6 \%$ \\
\hline Miaoli & $13.1 \%$ & $14.4 \%$ & $1.3 \%$ & $9.4 \%$ & $12.7 \%$ & $3.3 \%$ \\
\hline Taichung & $15.5 \%$ & $17.5 \%$ & $2.0 \%$ & $11.6 \%$ & $14.3 \%$ & $2.7 \%$ \\
\hline Changhua & $17.7 \%$ & $22.2 \%$ & $4.5 \%$ & $18.7 \%$ & $20.9 \%$ & $2.2 \%$ \\
\hline Nantou & $17.0 \%$ & $21.7 \%$ & $4.7 \%$ & $19.8 \%$ & $22.0 \%$ & $2.2 \%$ \\
\hline $\begin{array}{l}\text { Northern } \\
\text { average }\end{array}$ & $13.2 \%$ & $16.3 \%$ & $3.1 \%$ & $11.8 \%$ & $14.3 \%$ & $2.5 \%$ \\
\hline Touliu & $20.2 \%$ & $25.4 \%$ & $5.2 \%$ & $21.9 \%$ & $25.0 \%$ & $3.1 \%$ \\
\hline Chiayi & $16.3 \%$ & $21.7 \%$ & $5.4 \%$ & $20.4 \%$ & $20.9 \%$ & $0.5 \%$ \\
\hline Yenshueikang & $12.2 \%$ & $19.8 \%$ & $7.6 \%$ & $14.3 \%$ & $24.0 \%$ & $9.7 \%$ \\
\hline Tainan & $12.1 \%$ & $15.4 \%$ & $3.3 \%$ & $8.7 \%$ & $13.8 \%$ & $5.1 \%$ \\
\hline Fengshan & $11.5 \%$ & $17.1 \%$ & $5.6 \%$ & $14.8 \%$ & $18.4 \%$ & $3.6 \%$ \\
\hline Fanshuliao & $11.8 \%$ & $16.4 \%$ & $4.6 \%$ & $13.2 \%$ & $16.3 \%$ & $3.1 \%$ \\
\hline Ahou & $12.6 \%$ & $18.2 \%$ & $5.6 \%$ & $14.8 \%$ & $22.4 \%$ & $7.6 \%$ \\
\hline Hengchun & $12.4 \%$ & $16.0 \%$ & $3.6 \%$ & $14.3 \%$ & $21.4 \%$ & $7.1 \%$ \\
\hline $\begin{array}{l}\text { Southern } \\
\text { average }\end{array}$ & $13.6 \%$ & $18.8 \%$ & $5.2 \%$ & $15.3 \%$ & $20.3 \%$ & $5.0 \%$ \\
\hline $\begin{array}{l}\text { Taiwan } \\
\text { average }\end{array}$ & $13.4 \%$ & $17.4 \%$ & $4.0 \%$ & $13.3 \%$ & $17.0 \%$ & $3.7 \%$ \\
\hline
\end{tabular}

Source: Provisional TAIWAN LAND Survey OfFice [1906a], [1906b].

study, a village was selected in each township (庄) ${ }^{1}$ and all farming households in the village were questioned. The result is a cross-sectional survey of 271 villages containing a total of 37,543 households. Tables were compiled showing (1) the proportion of farm households who owed debt and how much they owed (as of November 15), (2) how much they had borrowed from each type of lender (fourteen

1 堡 and 里 were no longer used after 1919. 
types listed), (3) how much was borrowed in each of six interest rate brackets and whether the loan was backed by collateral, (4) what the loan was used for (eight uses listed including "other") and finally (5) the distribution of households in each area by family size and their respective borrowing patterns. For all but (5), there are separate tables for each of the three types of farmers: those who farm their own land, those who own some land but also farm others' land and those who are purely tenant farmers without land. Statistics for the first two groups were very similar, so this paper combines the two groups into one large group called "landed farmers."

In the second study, only one previously-surveyed village from each county (郡) in the five major prefectures (州) was selected. Thus the sample is limited to forty-five villages containing a total of 5,995 households. This second survey is somewhat more detailed. Most importantly, it contains tables showing how much was borrowed in each of the six interest rate brackets from each type of lender (fifteen types listed). In addition to the three types of farmers, there are also tables for non-farming landlords.

Table two shows the average interest rate paid by the different groups in the north and the south.

The Japanese survey divided loans into six categories: (1) interest-free loans, (2) loans with interest rates under 7\%, (3) loans with interest rates of $7 \%$ to $10 \%$, (4) loans with interest rates of $10 \%$ to $15 \%$, (5) loans with interest rates of $15 \%$ to $20 \%$ and (6) loans with interest rates over $20 \%$. To calculate the rate of interest, I ignored interest-free loans assuming that "interest-free" loans were probably subject to informal interest charges. These loans were often made by store-owners and landlords who could raise other prices to recompense themselves. To other loans I assign interest rates of 5\% to loans in category (2), 8.5\% to loans in category (3), $12.5 \%$ for loans in category (4), $17.5 \%$ for loans in category (5) and $25 \%$ for loans in category (6). The overall difference in interest rates between the north and south is $1.9 \%$ in 1933 and $1.1 \%$ in 1940 . The difference for tenant farmers is $3.8 \%$ and $1.9 \%$, respectively. This reflects the reliance of tenant farmers on informal markets where the difference in interest rates is greatest.

The Tax Office, Finance Bureau, Taiwan Government-General [1936, pp. 70-73] confirms the results of these surveys. This survey concentrated mainly on overall bank rates but it contains one table showing cross-sectional interest rates for loans by individuals backed by collateral. This information could be completely and systematically gathered because the collateral was locally registered with the authorities. Loans are broken down by area (five prefectures (州), three districts (廳), whether the collateral was in a city or a county, the year the loan was made (1930-1934) and the size of the loan (five categories, from under 500 yen to over 10,000 yen). The lowest interest rate, the mean interest rate and the highest interest rate were all recorded. Figure 1 shows the average mean interest rate in the north (Taipei, Hsinchu and Taichung), the south (Tainan and Kaohsiung), the eastern frontier (Taitung and Hualien) and the Pescadores. As the figure shows there was a considerable consistent difference in interest rates between the north, south and east in all five years. 
Table 2

Overall Interest Rates (by Prefecture and Group)

\begin{tabular}{|c|c|c|c|c|c|c|c|c|}
\hline Year & Group & Taipei & Hsinchu & $\begin{array}{l}\text { Tai- } \\
\text { chung }\end{array}$ & Tainan & $\begin{array}{l}\text { Kaoh- } \\
\text { siung }\end{array}$ & $\begin{array}{l}\text { East } \\
\text { Taiwan }\end{array}$ & $\begin{array}{l}\text { Pesca- } \\
\text { dores }\end{array}$ \\
\hline \multirow{4}{*}{1933} & $\begin{array}{l}\text { Land- } \\
\text { owners }\end{array}$ & $11.9 \%$ & $10.6 \%$ & $11.6 \%$ & $13.2 \%$ & $11.7 \%$ & $16.1 \%$ & $15.2 \%$ \\
\hline & $\begin{array}{l}\text { Part- } \\
\text { owners }\end{array}$ & $11.9 \%$ & $10.9 \%$ & $12.1 \%$ & $13.3 \%$ & $13.4 \%$ & $15.0 \%$ & $20.3 \%$ \\
\hline & $\begin{array}{l}\text { Tenant } \\
\text { farmers }\end{array}$ & $13.5 \%$ & $12.2 \%$ & $13.2 \%$ & $15.5 \%$ & $16.9 \%$ & $12.4 \%$ & $19.1 \%$ \\
\hline & $\begin{array}{l}\text { All } \\
\text { farmers }\end{array}$ & $12.3 \%$ & $11.1 \%$ & $12.2 \%$ & $13.6 \%$ & $14.1 \%$ & $13.7 \%$ & $15.9 \%$ \\
\hline \multirow{5}{*}{1940} & $\begin{array}{l}\text { Land- } \\
\text { owners }\end{array}$ & $7.0 \%$ & $6.5 \%$ & $7.2 \%$ & $8.3 \%$ & $8.1 \%$ & n.d. & n.d. \\
\hline & $\begin{array}{l}\text { Part- } \\
\text { owners }\end{array}$ & $6.9 \%$ & $6.9 \%$ & $7.3 \%$ & $7.8 \%$ & $8.1 \%$ & n.d. & n.d. \\
\hline & $\begin{array}{l}\text { Tenant } \\
\text { farmers }\end{array}$ & $8.1 \%$ & $7.5 \%$ & $7.5 \%$ & $9.3 \%$ & $9.6 \%$ & n.d. & n.d. \\
\hline & $\begin{array}{l}\text { All } \\
\text { farmers }\end{array}$ & $7.4 \%$ & $7.0 \%$ & $7.3 \%$ & $8.2 \%$ & $8.5 \%$ & n.d. & n.d. \\
\hline & $\begin{array}{l}\text { Land- } \\
\text { lords }\end{array}$ & $7.4 \%$ & $6.1 \%$ & $6.7 \%$ & $5.3 \%$ & $6.8 \%$ & n.d. & n.d. \\
\hline
\end{tabular}

Note: Calculated from Agriculture OfFice, Agriculture And Industry Bureau, TAIWAN Government-GENERAL [1935, Table 4] and [1940, Table 4].

Table three shows the results of six regressions used to put this data into simple form. There are two regressions for each of the three dependent variables: the mean interest rate, the high interest rate and the low interest rate. The first regression uses only one set of independent dummy variables, those for the area in which the loan was recorded (Taichung, the most southerly prefecture in the north, is the reference group). In the second regression, two other sets of variables are added. One set of two variables distinguishes loans recorded in cities. Each of the five prefectures contained cities. One variable is a cross-dummy variable which is one for cities in the northern prefectures (Taipei, Hsinchu and Taichung) and zero elsewhere, and the other is a cross dummy for cities in the southern prefectures (Tainan and Kaohsiung). The second set of four variables are cross-variables to distinguish the effect of the size of the loan in different areas. The data gives five categories of loan sizes: (1) under 500 yen, (2) under 1000 yen, (3) under 5000 yen, (4) under 10,000 yen and (5) over 10,000 yen. Most informal-sector farm loans were in the first category. In these regressions, first category loans are assigned a zero value, 
Table 3

Interest Rates on Collateralized Loans, 1930-1934

\begin{tabular}{|c|c|c|c|c|c|c|}
\hline $\begin{array}{l}\text { Independent } \\
\text { variables }\end{array}$ & $\begin{array}{l}\text { Mean } \\
\text { rate }\end{array}$ & $\begin{array}{l}\text { Mean } \\
\text { rate }\end{array}$ & $\begin{array}{l}\text { Highest } \\
\text { rate }\end{array}$ & $\begin{array}{l}\text { Highest } \\
\text { rate }\end{array}$ & $\begin{array}{l}\text { Lowest } \\
\text { rate }\end{array}$ & $\begin{array}{l}\text { Lowest } \\
\text { rate }\end{array}$ \\
\hline Intercept & $\begin{array}{l}14.19 * * \\
(0.31)\end{array}$ & $\begin{array}{l}15.48 * * \\
(0.26)\end{array}$ & $\begin{array}{l}18.03 * * \\
(0.66)\end{array}$ & $\begin{array}{l}22.62 * * \\
(0.59)\end{array}$ & $\begin{array}{l}10.65^{* *} \\
(0.37)\end{array}$ & $\begin{array}{l}10.08 * * \\
(0.54)\end{array}$ \\
\hline Taipei & $\begin{array}{l}-1.62 * * \\
(0.44)\end{array}$ & $\begin{array}{l}-1.65^{* *} \\
(0.25)\end{array}$ & $\begin{array}{l}-1.39 \\
(0.94)\end{array}$ & $\begin{array}{l}-1.49 * * \\
(0.56)\end{array}$ & $\begin{array}{l}-1.39 * \\
(0.53)\end{array}$ & $\begin{array}{l}-1.38 * * \\
(0.51)\end{array}$ \\
\hline Hsinchu & $\begin{array}{l}-1.55^{* *} \\
(0.47)\end{array}$ & $\begin{array}{l}-2.02 * * \\
(0.28)\end{array}$ & $\begin{array}{l}-1.38 \\
(1.02)\end{array}$ & $\begin{array}{l}-2.86^{* * *} \\
(0.62)\end{array}$ & $\begin{array}{l}-1.30 * \\
(0.58)\end{array}$ & $\begin{array}{l}-1.13^{*} \\
(0.57)\end{array}$ \\
\hline Tainan & $\begin{array}{l}0.88^{*} \\
(0.44)\end{array}$ & $\begin{array}{l}1.34 * * \\
(0.39)\end{array}$ & $\begin{array}{l}1.26 \\
(0.95)\end{array}$ & $\begin{array}{l}1.70 \\
(0.86)\end{array}$ & $\begin{array}{l}0.25 \\
(0.54)\end{array}$ & $\begin{array}{l}-0.43 \\
(0.80)\end{array}$ \\
\hline Kaohsiung & $\begin{array}{l}1.42 * * \\
(0.45)\end{array}$ & $\begin{array}{l}1.78^{* *} \\
(0.39)\end{array}$ & $\begin{array}{l}3.05^{* *} * \\
(0.97)\end{array}$ & $\begin{array}{l}3.23 * * \\
(0.86)\end{array}$ & $\begin{array}{l}-0.39 \\
(0.54)\end{array}$ & $\begin{array}{l}1.05 \\
(0.79)\end{array}$ \\
\hline Taitung & $\begin{array}{l}5.89 * * \\
(0.60)\end{array}$ & $\begin{array}{l}7.86^{* * *} \\
(0.45)\end{array}$ & $\begin{array}{l}4.94 * * \\
(1.30)\end{array}$ & $\begin{array}{l}4.77 * * \\
(1.00)\end{array}$ & $\begin{array}{l}2.98 * * \\
(0.73)\end{array}$ & $\begin{array}{l}3.59 * * \\
(0.92)\end{array}$ \\
\hline Hualien & $\begin{array}{l}3.62 * * \\
(0.57)\end{array}$ & $\begin{array}{l}6.51 * * \\
(0.46)\end{array}$ & $\begin{array}{l}4.78 * * \\
(1.22)\end{array}$ & $\begin{array}{l}5.83 * * \\
(1.03)\end{array}$ & $\begin{array}{l}-0.13 \\
(0.69)\end{array}$ & $\begin{array}{l}0.49 \\
(0.95)\end{array}$ \\
\hline Pescadores & $\begin{array}{l}0.71 \\
(0.63)\end{array}$ & $\begin{array}{l}1.14^{*} \\
(0.56)\end{array}$ & $\begin{array}{l}2.61^{*} \\
(1.36)\end{array}$ & $\begin{array}{l}2.91 * \\
(1.26)\end{array}$ & $\begin{array}{l}-1.12 \\
(0.77)\end{array}$ & $\begin{array}{l}-3.48^{* *} \\
(1.16)\end{array}$ \\
\hline $\begin{array}{l}\text { Northern } \\
\text { cities }\end{array}$ & & $\begin{array}{l}0.22 \\
(0.21)\end{array}$ & & $\begin{array}{l}-0.37 \\
(0.48)\end{array}$ & & $\begin{array}{l}0.12 \\
(0.44)\end{array}$ \\
\hline $\begin{array}{l}\text { Southern } \\
\text { cities }\end{array}$ & & $\begin{array}{l}0.94 * * \\
(0.26)\end{array}$ & & $\begin{array}{l}1.37 * \\
(0.58)\end{array}$ & & $\begin{array}{l}1.06^{*} \\
(0.54)\end{array}$ \\
\hline $\begin{array}{l}\text { Loan size } \\
\text { in north }\end{array}$ & & $\begin{array}{l}-0.77 * * \\
(0.08)\end{array}$ & & $\begin{array}{l}-2.30^{* * *} \\
(0.18)\end{array}$ & & $\begin{array}{l}0.26 \\
(0.17)\end{array}$ \\
\hline $\begin{array}{l}\text { Loan size } \\
\text { in south }\end{array}$ & & $\begin{array}{l}-1.29 * * \\
(0.10)\end{array}$ & & $\begin{array}{l}-3.22 * * \\
(0.22)\end{array}$ & & $\begin{array}{l}0.40 \\
(0.21)\end{array}$ \\
\hline $\begin{array}{l}\text { Loan size } \\
\text { in east }\end{array}$ & & $\begin{array}{l}-2.58 * * \\
(0.16)\end{array}$ & & $\begin{array}{l}-3.42 * * \\
(0.36)\end{array}$ & & $\begin{array}{l}-0.03 \\
(0.33)\end{array}$ \\
\hline $\begin{array}{l}\text { Loan size } \\
\text { in Pescadores }\end{array}$ & & $\begin{array}{l}-1.78 * * \\
(0.39)\end{array}$ & & $\begin{array}{l}-4.90 * * \\
(0.86)\end{array}$ & & $\begin{array}{l}2.92^{* * *} \\
(0.79)\end{array}$ \\
\hline $\begin{array}{l}\text { Adjusted } \\
R 2\end{array}$ & 0.480 & 0.833 & 0.188 & 0.721 & 0.146 & 0.219 \\
\hline
\end{tabular}

Note: The sample size is 270 for each regression. The data comes from TAX OfFICE, FinANCE Bureau, TAIWAN GOVERnMENT-GENERAL [1936, Table 22-2]. 
Figure 1

Average Mean Monthly Interest Rates, 1930-1934

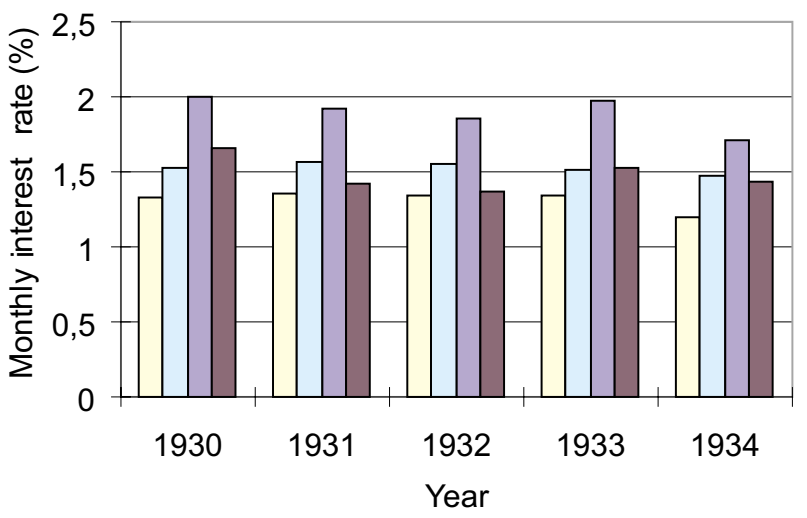

$\square$ North $\square$ South $\square$ East $\square$ Pescadores

Note: From Tax Office, Finance Bureau, Taiwan Government-General [1936, Table 22-2].

second category loans are assigned a value of one, third category loans are assigned a value of two, etc. This loan size variable is then crossed with four area dummies: one for the north (Taipei, Hsinchu and Taichung), one for the south (Tainan and Kaohsiung), one for the east (Taitung and Hualien) and one for the Pescadores.

The regressions using the mean interest rate as the dependent variable are most important. They show that both Taipei and Hsinchu had significantly lower interest rates than Taichung (at the 99\% confidence level) while Tainan and Kaohsiung had significantly higher rates than Taichung (also at the 99\% confidence level once other variables are included). This generally agrees with the results from the Basic Agricultural Survey. The only difference being that the agricultural survey shows that interest rates in Taipei prefecture were about as high as those in Taichung prefecture. It also confirms that this pattern was not just an aberration that happened to occur in 1933 and 1940. The second regression shows that larger loans had lower interest rates. This could be explained by the fact that larger loans often have lower information costs (e.g. credit checks) and enforcement costs per amount borrowed. The difference between areas is most pronounced for small loans for which these costs were greatest relative to loan size. The regression also shows that the north-south difference in interest rates was generally greater in urban areas than in rural areas. This shows that the higher southern interest rates were not specific to the agricultural sector. The statistics for the highest and lowest interest rates are troublesome figures. Both rates will be influenced by factors such as the number of loans and will be very sensitive to outlying observations. The lowest rate should be the rate on the loans with the least risk (or transaction costs). Both regressions using 
the lowest interest rate show a much less pronounced difference between the north and south. The interest on low risk loans differed relatively little between regions. The highest rate will be very sensitive to risk and it shows a difference between the different regions as great as the difference shown by the average rate.

After 1945, during the KMT period, other cross-sectional studies on interest rates were done. These show that the interest rate differential between north and south continued well into the post-war period. The one exceptional region was the Taipei area. This area received a massive influx of mainland refugees and was the capital for the new government. Interest rates around Taipei rose to or exceeded southern levels before gradually lowering. Two studies should be noted.

In the first of these studies, the DEPARTMENT OF AGRICULTURE AND FORESTRY, TAIWAN PROVINCIAL GOVERNMENT [1950] did a survey of agriculture finance in 1949 which closely imitated the earlier Japanese surveys. This reports results for 11,405 farm families in 100 villages across the island. Of these 6,750 had borrowed money. The estimated average interest rate was $20.7 \%$ in the Taipei area, $17.8 \%$ in the Hsinchu-Taichung area and $21.1 \%$ in the south. This study was done just as the post-war hyperinflation was being brought under control and the calculated mean values are just rough estimates but, by any measure, there was a large difference between Hsinchu-Taichung interest rates and those of the south.

The second source of data is a compilation of interest rates from 1952 to mid1965 done by the Central Bank. The bank kept records of the interest rates charged by private money lenders in twenty-two localities across the island (ECONOMIC Research Section, Central Bank of China [1964, pp. 69f.]). The bank's tables confirm that the basic interest rate pattern shown by the 1949 survey continued into the early 1960s. Interest rates for the old Tainan and Kaohsiung prefecture areas in the south are consistently above those for the Hsinchu-Taichung region. In the 1952-1955 period, estimated average monthly interest rates on secured loans for Hsinchu-Taichung and the south were respectively $3.6 \%$ and $4.3 \%$. During the 1956-1960 period the respective rates were $3.2 \%$ and $3.5 \%$ and in the $1961-1964$ period, $2.5 \%$ and $2.9 \%$. The Taipei rates are shown to have risen above southern levels in the 1950s and only drop below the southern rates after 1960.

\section{The Existence of the Risk Premium}

Were the higher interest rates in the south due to a risk premium ${ }^{2}$ or just to a lack of capital in the south relative to demand? Statistics are too limited to allow one conclusive convincing test. With the given statistics, this question can be fruitfully approached from five directions. Each approach points to a north-south risk premium differential.

The first approach is to examine whether there was a significant degree of interregional lending. One does not have to show that all farmers had the option of

2 In this paper, I am using "risk premium" in a broad sense that includes any transaction costs incurred in monitoring and enforcing a loan. 
borrowing directly from other regions. All that one needs to show is that there were a significant number of such farmers in both areas so that a higher expected return to loans in one area would lead to a correcting influx of capital driving down interest rates. There is little information on inter-regional lending during the early period of Japanese rule, but by the 1930s inter-regional lending was very important. Table four shows the source of loans for different groups of farmers, north and south, in 1933 and 1940. Approximately one-third of loans to landed farmers came from banks and the majority of farmers owned land. These banks were profit-seeking island-wide organizations with branches and loans in both the north and south.

Another important source of loans was sugar corporations. These organizations were usually part of large conglomerates with strong ties to banks. They were regional monopsonies to which all sugar farmers in an area were required by law to sell their sugar cane production. The sugar corporations, thus, had an easy way of enforcing loan repayments and it is reasonable to see them as middlemen guaranteeing bank loans.

Finally, there was a significant amount of borrowing from credit cooperatives, primarily professional cooperative societies (產業組織). These organizations were not inter-regional but they too worked with banks and could thus be used to move money in and out of an area. Together, these three sources of loans accounted for about half the loans to landed farmers and about a quarter of loans to tenant farmers in 1933. By 1940, even tenant farmers received half their loans from these sources. Besides these organizations there was a postal savings system operating throughout the island so that local lenders could easily pull their money out of the capital market if they found returns too low. Northern and southern markets may not have been integrated in any strict sense, but it is hard to believe that, in the 1930s, a long-term difference in expected returns to loans could persist.

A second approach to identifying the reason behind the north-south interest rate differential is to look at the returns to holding land. If capital could flow easily between north and south, the returns to holding land in each region should be similar. In any given area, a person with money to invest could either lend it at interest or buy paddy land or dry field and collect land rent. Within any given area, the expected returns to these investments should be very similar. If the expected return to loans fell below the expected return to land, then money would be pulled out of the loan market and used to buy land, bidding up the price of land and thus lowering its expected return. If the expected return to loans rose above the return to holding land, the opposite would occur. If the interest rate in an area is higher than the rate of return to land rents, this shows the risk to lending money (the risk that the loaner may default) is higher than the risk involved in collecting rent. If the risk of default was higher in the south, than ceteris paribus, the difference between the interest rate and the return to land rent should have been higher in the south. This appears to have been the case.

As previously noted, the data from the two early studies done circa 1906 are not as reliable as the data from the 1930s, but the two early studies do suggest a higher risk premium in the south. The estimated returns to those purchasing dry fields or paddy 
Table 4

Money Borrowed per Farm Household (by Source)

\begin{tabular}{lllllll}
\hline Year Group & $\begin{array}{llll}\text { Bank } \\
\text { loans }\end{array}$ & $\begin{array}{l}\text { Col- } \\
\text { lective } \\
\text { loans }\end{array}$ & $\begin{array}{l}\text { Sugar } \\
\text { corp. } \\
\text { loans }\end{array}$ & $\begin{array}{l}\text { Total } \\
\text { formal } \\
\text { loans }\end{array}$ & $\begin{array}{l}\text { Total } \\
\text { informal } \\
\text { loans }\end{array}$ & $\begin{array}{l}\text { Overall } \\
\text { total }\end{array}$ \\
\hline
\end{tabular}

\begin{tabular}{|c|c|c|c|c|c|c|c|}
\hline \multirow{4}{*}{1933} & $\begin{array}{l}\text { Northern } \\
\text { landholding } \\
\text { farmers }\end{array}$ & $\begin{array}{l}170 \\
(26.6 \%)\end{array}$ & $\begin{array}{l}87 \\
(13.6 \%)\end{array}$ & $\begin{array}{l}9 \\
(1.4 \%)\end{array}$ & $\begin{array}{l}266 \\
(41.6 \%)\end{array}$ & $\begin{array}{l}374 \\
(58.4 \%)\end{array}$ & $\begin{array}{l}640 \\
(100.0 \%)\end{array}$ \\
\hline & $\begin{array}{l}\text { Southern } \\
\text { landholding } \\
\text { farmers }\end{array}$ & $\begin{array}{l}155 \\
(31.1 \%)\end{array}$ & $\begin{array}{l}81 \\
(16.2 \%)\end{array}$ & $\begin{array}{l}44 \\
(8.8 \%)\end{array}$ & $\begin{array}{l}280 \\
(56.1 \%)\end{array}$ & $\begin{array}{l}219 \\
(43.9 \%)\end{array}$ & $\begin{array}{l}499 \\
(100.0 \%)\end{array}$ \\
\hline & $\begin{array}{l}\text { Northern } \\
\text { tenant } \\
\text { farmers }\end{array}$ & $\begin{array}{l}7 \\
(2.7 \%)\end{array}$ & $\begin{array}{l}39 \\
(14.9 \%)\end{array}$ & $\begin{array}{l}10 \\
(3.8 \%)\end{array}$ & $\begin{array}{l}56 \\
(21.4 \%)\end{array}$ & $\begin{array}{l}206 \\
(78.6 \%)\end{array}$ & $\begin{array}{l}262 \\
(100.0 \%)\end{array}$ \\
\hline & $\begin{array}{l}\text { Southern } \\
\text { tenant } \\
\text { farmers }\end{array}$ & $\begin{array}{l}6 \\
(2.3 \%)\end{array}$ & $\begin{array}{l}42 \\
(16.1 \%)\end{array}$ & $\begin{array}{l}21 \\
(8.0 \%)\end{array}$ & $\begin{array}{l}69 \\
(26.4 \%)\end{array}$ & $\begin{array}{l}192 \\
(73.6 \%)\end{array}$ & $\begin{array}{l}261 \\
(100.0 \%)\end{array}$ \\
\hline \multirow{6}{*}{1940} & $\begin{array}{l}\text { Northern } \\
\text { landholding } \\
\text { farmers }\end{array}$ & $\begin{array}{l}219 \\
(35.3 \%)\end{array}$ & $\begin{array}{l}177 \\
(28.5 \%)\end{array}$ & $\begin{array}{l}45 \\
(7.2 \%)\end{array}$ & $\begin{array}{l}441 \\
(71.0 \%)\end{array}$ & $\begin{array}{l}180 \\
(29.0 \%)\end{array}$ & $\begin{array}{l}621 \\
(100.0 \%)\end{array}$ \\
\hline & $\begin{array}{l}\text { Southern } \\
\text { landholding } \\
\text { farmers }\end{array}$ & $\begin{array}{l}296 \\
(39.5 \%)\end{array}$ & $\begin{array}{l}196 \\
(26.2 \%)\end{array}$ & $\begin{array}{l}129 \\
(17.2 \%)\end{array}$ & $\begin{array}{l}621 \\
(82.9 \%)\end{array}$ & $\begin{array}{l}128 \\
(17.1 \%)\end{array}$ & $\begin{array}{l}749 \\
(100.0 \%)\end{array}$ \\
\hline & $\begin{array}{l}\text { Northern } \\
\text { tenant } \\
\text { farmers }\end{array}$ & $\begin{array}{l}28 \\
(8.3 \%)\end{array}$ & $\begin{array}{l}105 \\
(31.1 \%)\end{array}$ & $\begin{array}{l}33 \\
(9.8 \%)\end{array}$ & $\begin{array}{l}166 \\
(49.1 \%)\end{array}$ & $\begin{array}{l}172 \\
(50.9 \%)\end{array}$ & $\begin{array}{l}338 \\
(100.0 \%)\end{array}$ \\
\hline & $\begin{array}{l}\text { Southern } \\
\text { tenant } \\
\text { farmers }\end{array}$ & $\begin{array}{l}9 \\
(2.7 \%)\end{array}$ & $\begin{array}{l}117 \\
(35.5 \%)\end{array}$ & $\begin{array}{l}93 \\
(28.2 \%)\end{array}$ & $\begin{array}{l}219 \\
(66.4 \%)\end{array}$ & $\begin{array}{l}111 \\
(33.6 \%)\end{array}$ & $\begin{array}{l}330 \\
(100.0 \%)\end{array}$ \\
\hline & $\begin{array}{l}\text { Northern } \\
\text { landlords }\end{array}$ & $\begin{array}{l}642 \\
(39.6 \%)\end{array}$ & $\begin{array}{l}209 \\
(12.9 \%)\end{array}$ & $\begin{array}{l}12 \\
(0.7 \%)\end{array}$ & $\begin{array}{l}863 \\
(53.2 \%)\end{array}$ & $\begin{array}{l}759 \\
(46.8 \%)\end{array}$ & $\begin{array}{l}1622 \\
(100.0 \%)\end{array}$ \\
\hline & $\begin{array}{l}\text { Southern } \\
\text { landlords }\end{array}$ & $\begin{array}{l}4209 \\
(78.5 \%)\end{array}$ & $\begin{array}{l}155 \\
(2.9 \%)\end{array}$ & $\begin{array}{l}857 \\
(16.0 \%)\end{array}$ & $\begin{array}{l}5221 \\
(97.4 \%)\end{array}$ & $\begin{array}{l}141 \\
(2.6 \%)\end{array}$ & $\begin{array}{l}5362 \\
(100.0 \%)\end{array}$ \\
\hline
\end{tabular}

Note: Calculated from Agriculture OfFice, Agriculture and Industry Bureau, TAIWAN Government-General [1935, Table 3] and [1940, Table 3]. The percentage of total borrowing in each category is shown in parentheses. 
land are shown in table one. Paddy rent was usually paid in rice, so the Japanese researchers compared this rent to the interest rate of loans the interest on which was also paid in rice. Dry field rent was not paid in rice so the researchers compared it to the interest rate of purely monetary loans. Both the returns to holding land and the rates of interest were higher in the middle of Taiwan suggesting that there was a relative shortage of capital in this area. Land rents were somewhat higher in the south than the north but to a much smaller extent than the rates of interest. Both tables show that the spread between interest rates and land rents was, with few exceptions, higher in the south. Unfortunately, one should also note that the returns to holding dry field in each area are reported to be quite different than the returns to holding paddy land. This could indicate that the two studies were done at different times, that there is a significant and variable risk to holding the different types of land or that these studies simply contain a great deal of human error.

Better data is available for the later period of Japanese rule. Table five shows the results of an OLS regression on the calculated returns to land in Taiwan based on the results of the survey recorded in volumes 25 and 26 of the Basic Agricultural Survey (Agriculture OfFice, Agriculture AND Industry Bureau, TAIWAN GOVERNMENT-GENERAL [1930a], [1930b]).

This survey was done in 1927 and it recorded the estimated price, the estimated yield (in yen), the grade and some more detailed information for a wide variety of fields across the island. Fields were divided into four types: double-cropped pad-

Table 5

The Return to Land Investment in Taiwan

\begin{tabular}{ll}
\hline Independent variables & Coefficients and standard errors \\
\hline Intercept & $0.051^{* *}$ \\
& $(0.005)$ \\
Dry field dummy & 0.017 \\
& $(0.009)$ \\
Grade of dry field & 0.000 \\
& $(0.001)$ \\
Grade of paddy & $0.003 * *$ \\
& $(0.001)$ \\
North Taiwan & -0.002 \\
& $(0.002)$ \\
East Taiwan & $0.029 * *$ \\
& $(0.004)$ \\
\hline
\end{tabular}

Note: There are 442 observations. The adjusted $R$-squared value is 0.186 . Data is from Agriculture Office, Agriculture and Industry Bureau, TaIWAN GovernmentGeNERAL [1930a, Table 1] and [1930b, Table 1]. 
dies (2,799 observations), single-cropped paddies (1,320 observations), dry fields (3,192 observations) and tea groves (512 observations). The reported regression uses double-cropped paddy data and the dry field data ${ }^{3}$ and uses average values reported for average fields for each township (庄). The dependent variable is the return to owning the field which is calculated by dividing the estimated annual yield to the landlord (less taxes and other costs) by the estimated price of the land. The independent variables consist of (1) a dummy variable to distinguish dry field from paddy, (2) two variables representing the average grade of land being reported (one for the grade of paddy land, the other for the grade of dry land) and (3) a set of regional dummies (one for the north and one for the east). The reference group is southern double-cropped paddy land. The regression shows that the returns to land ownership were much higher in eastern Taiwan. This indicates that there was a shortage of capital in this sparsely-populated frontier region which might explain the higher interest rates found there. But the difference in returns between north and south Taiwan were quite small. The possibility that there was no difference can not be rejected and the possibility that the difference was large enough to explain half the difference in 1933 interest rates can be rejected at the $99 \%$ level of confidence. The regression also shows that the land's grade affected the return for paddy fields. The higher the grade, the worse the field quality and the higher the average return. This suggests that poor quality paddy land may have had a more variable return leading to a risk premium for investment in low quality land. The importance of this regression is that it shows that by 1927 , capital mobility was great enough to seemingly eliminate any important regional difference in the rate of return to investment in land in western Taiwan. Thus, this approach also suggests that the north-south interest rate differential was due to a risk premium.

A third approach to identifying the reason behind the north-south interest rate differential is to look at the interest rates on different types of loans, north and south. As was shown in table three, the difference between north and south was smallest for the safest loans (those with the lowest interest rate). The 1940 study gives further evidence of this fact. It reports the interest rates on loans by source. These are shown in table six. The difference between northern and southern interest rates is least for banks and sugar corporations, somewhat greater for collectives and clearly greatest for informal loans from individuals. Informal loans were primarily loans from friends, family and neighbors, but also included loans from landlords and merchants.

As can be seen by the rate of interest, banks specialized in making the least risky loans while individuals specialized in riskier loans. The least risky group to which to make loans would have been landlords since they possessed the most collateral. The riskiest group would have been tenant farmers who lacked collateral. As would be expected, table six shows the smallest differential in north-south interest rates is between northern and southern landlords while the greatest difference is between

3 There were few single-cropped paddies in the north and almost no tea groves in the south. 
Table 6

Annual Interest Rates by Source, 1940

\begin{tabular}{lllllll}
\hline Region & Group & $\begin{array}{l}\text { Bank } \\
\text { loans }\end{array}$ & $\begin{array}{l}\text { Collective } \\
\text { loans }\end{array}$ & $\begin{array}{l}\text { Sugar } \\
\text { corp. } \\
\text { loans }\end{array}$ & $\begin{array}{l}\text { Informal } \\
\text { loans }\end{array}$ & $\begin{array}{l}\text { Overall } \\
\text { interest } \\
\text { rate }\end{array}$ \\
\hline \multirow{2}{*}{ North } & $\begin{array}{l}\text { Landholding } \\
\text { farmers }\end{array}$ & $5.7 \%$ & $7.2 \%$ & $5.3 \%$ & $9.2 \%$ & $6.9 \%$ \\
$\begin{array}{l}\text { Tenant } \\
\text { farmers }\end{array}$ & $5.5 \%$ & $7.6 \%$ & $6.5 \%$ & $9.2 \%$ & $7.9 \%$ \\
& $\begin{array}{l}\text { Non-farming } \\
\text { landlords }\end{array}$ & $5.7 \%$ & $7.6 \%$ & $5.1 \%$ & $8.8 \%$ & $7.2 \%$ \\
\hline South & $\begin{array}{l}\text { Landholding } \\
\text { farmers } \\
\text { Tenant } \\
\text { farmers }\end{array}$ & $6.3 \%$ & $8.7 \%$ & $5.3 \%$ & $13.7 \%$ & $8.0 \%$ \\
\hline $\begin{array}{l}\text { Non-farming } \\
\text { landlords }\end{array}$ & $5.6 \%$ & $9.1 \%$ & $5.9 \%$ & $14.1 \%$ & $9.7 \%$ \\
\hline
\end{tabular}

Note: Calculated from Agriculture OfFice, Agriculture And Industry Bureau, TAIWAN GOVERnMENT-GENERAL [1940, Table 5].

tenant farmers. This is not only true overall but holds true within the two most important categories, bank loans and informal loans. There is thus a clear positive correlation between the risk of making a loan and the size of the north-south interest rate differential suggesting that it is risk which is driving a wedge between the interest rates.

A fourth approach is to examine directly the amount middlemen charged when they acted as guarantors of a loan. This can be done in the case of landlords. The 1940 study shows that about $5 \%$ of loans to farmers came from landlords and that the large majority of landlords were in debt. Landlords were thus acting as middlemen, borrowing money at lower interest rates and then lending this money to their tenants and other farmers. Table seven shows the interest rates at which landlords borrowed in different areas and the rate they charged to their own borrowers. ${ }^{4}$ As the last three columns show, southern landlords actually borrowed money at a somewhat lower rate than northern landlords, but charged higher rates to their tenants and other farmers who borrowed from them.

This directly indicates that landlords faced greater risk in making loans in the south than in the north. One might be tempted to attribute this differential to greater

\footnotetext{
4 Many loans given by landlords to tenants had no explicit rate of interest. In what follows, I ignore these loans.
} 
Table 7

Loans through Landlords, 1940

\begin{tabular}{|c|c|c|c|c|c|c|c|}
\hline Place & $\begin{array}{l}\text { Total } \\
\text { landlords } \\
\text { surveyed }\end{array}$ & $\begin{array}{l}\text { Total } \\
\text { landlords } \\
\text { in areas } \\
\text { in which } \\
\text { landlords } \\
\text { made } \\
\text { loans }\end{array}$ & $\begin{array}{l}\text { Percent } \\
\text { of land- } \\
\text { lords } \\
\text { in loan } \\
\text { areas } \\
\text { in debt }\end{array}$ & $\begin{array}{l}\text { Interest } \\
\text { rate } \\
\text { faced } \\
\text { by all } \\
\text { landlords } \\
\text { surveyed }\end{array}$ & $\begin{array}{l}\text { Interest } \\
\text { rate } \\
\text { faced by } \\
\text { landlords } \\
\text { in loan } \\
\text { areas }\end{array}$ & $\begin{array}{l}\text { Interest } \\
\text { rate of } \\
\text { landlord } \\
\text { loans to } \\
\text { tenant } \\
\text { farmers }\end{array}$ & $\begin{array}{l}\text { Interest } \\
\text { rate of } \\
\text { landlord } \\
\text { loans to } \\
\text { land- } \\
\text { owning } \\
\text { farmers }\end{array}$ \\
\hline Taipei & $\begin{array}{l}114 \\
(9)\end{array}$ & $\begin{array}{l}12 \\
(3)\end{array}$ & $67 \%$ & $\begin{array}{l}7.4 \% \\
(7)\end{array}$ & $\begin{array}{l}6.6 \% \\
(3)\end{array}$ & $\begin{array}{l}5.8 \% \\
\text { (3) }\end{array}$ & None \\
\hline $\begin{array}{l}\text { Hsin- } \\
\text { chu }\end{array}$ & $\begin{array}{l}41 \\
(8)\end{array}$ & $\begin{array}{l}23 \\
(5)\end{array}$ & $91 \%$ & $\begin{array}{l}6.1 \% \\
(6)\end{array}$ & $\begin{array}{l}6.0 \% \\
(5)\end{array}$ & $\begin{array}{l}6.5 \% \\
(4)\end{array}$ & $\begin{array}{l}7.4 \% \\
\text { (2) }\end{array}$ \\
\hline $\begin{array}{l}\text { Tai- } \\
\text { chung }\end{array}$ & $\begin{array}{l}72 \\
(11)\end{array}$ & $\begin{array}{l}38 \\
(5)\end{array}$ & $95 \%$ & $\begin{array}{l}6.7 \% \\
(10)\end{array}$ & $\begin{array}{l}6.8 \% \\
(5)\end{array}$ & $\begin{array}{l}6.7 \% \\
(4)\end{array}$ & $\begin{array}{l}12.5 \% \\
\text { (2) }\end{array}$ \\
\hline $\begin{array}{l}\text { North } \\
\text { Taiwan }\end{array}$ & $\begin{array}{l}227 \\
(27)\end{array}$ & $\begin{array}{l}73 \\
(13)\end{array}$ & $89 \%$ & $\begin{array}{l}6.8 \% \\
(23)\end{array}$ & $\begin{array}{l}6.5 \% \\
(13)\end{array}$ & $\begin{array}{l}6.4 \% \\
\text { (11) }\end{array}$ & $\begin{array}{l}11.2 \% \\
(4)\end{array}$ \\
\hline Tainan & $\begin{array}{l}76 \\
(10)\end{array}$ & $\begin{array}{l}63 \\
(8)\end{array}$ & $81 \%$ & $\begin{array}{l}5.3 \% \\
(10)\end{array}$ & $\begin{array}{l}5.3 \% \\
(8)\end{array}$ & $\begin{array}{l}11.8 \% \\
(5)\end{array}$ & $\begin{array}{l}14.8 \% \\
(8)\end{array}$ \\
\hline $\begin{array}{l}\text { Kaoh- } \\
\text { siung }\end{array}$ & $\begin{array}{l}22 \\
(7)\end{array}$ & $\begin{array}{l}13 \\
(4)\end{array}$ & $62 \%$ & $\begin{array}{l}6.8 \% \\
(4)\end{array}$ & $\begin{array}{l}7.3 \% \\
(3)\end{array}$ & $\begin{array}{l}16.4 \% \\
(4)\end{array}$ & $\begin{array}{l}18.8 \% \\
\text { (1) }\end{array}$ \\
\hline $\begin{array}{l}\text { South } \\
\text { Taiwan }\end{array}$ & $\begin{array}{l}98 \\
(18)\end{array}$ & $\begin{array}{l}76 \\
(12)\end{array}$ & $78 \%$ & $\begin{array}{l}5.4 \% \\
(14)\end{array}$ & $\begin{array}{l}5.4 \% \\
\text { (11) }\end{array}$ & $\begin{array}{l}12.2 \% \\
(9)\end{array}$ & $\begin{array}{l}15.0 \% \\
\text { (9) }\end{array}$ \\
\hline
\end{tabular}

Note: The number in parentheses is the number of townships (庄). Calculated from Agriculture OfFice, Agriculture and Industry Bureau, TAiwan GovernmentGENERAL [1940, Tables 1 and 5].

exploitation of a monopoly relationship by southern landlords. However, the statistics show that landlords actually charged higher interest rates to independent landed farmers than to their tenants. This is what one would expect if the interest rate spread were due to a risk premium. The landlord is in a much better position to collect loans from his tenants than from independent landed farmers. If the landlord were charging higher interest due to an ability to exploit other people, one would expect interest rates to be higher for tenants over whom he could be assumed to have more power. 
The final approach to establishing that the interest rate differential was due to a higher southern risk premium is to observe the legal record for evidence that loan defaults were higher in the south than in the north. The Taiwan GovernmentGeneral's Statistical Annual records yearly case statistics reported by local Japanese arbitration courts. From 1910 to 1933, these courts reported the number of cases considered by area, reason for conflict and the race of those involved (RESEARCH OFFICE, SECRETARIAT, TAIWAN GOVERNMENT-GENERAL [1905-1940, years 19101933]). Figure 2 shows that throughout the period, among Taiwanese, there were considerably more money-related cases per person in the south than in the north, but there was no north-south difference for non-money-related cases. The difference in Taiwanese money-related cases was narrowing as time progressed. This may reflect the fact that southerners were increasingly turning away from the informal market and borrowing from formal institutions. Even during the Japanese period, most money disputes probably did not go to court. The larger number of Taiwanese money-related cases in the south suggests that local informal enforcement measures were more effective in the north.

Figure 2

Civil Suits among Taiwanese
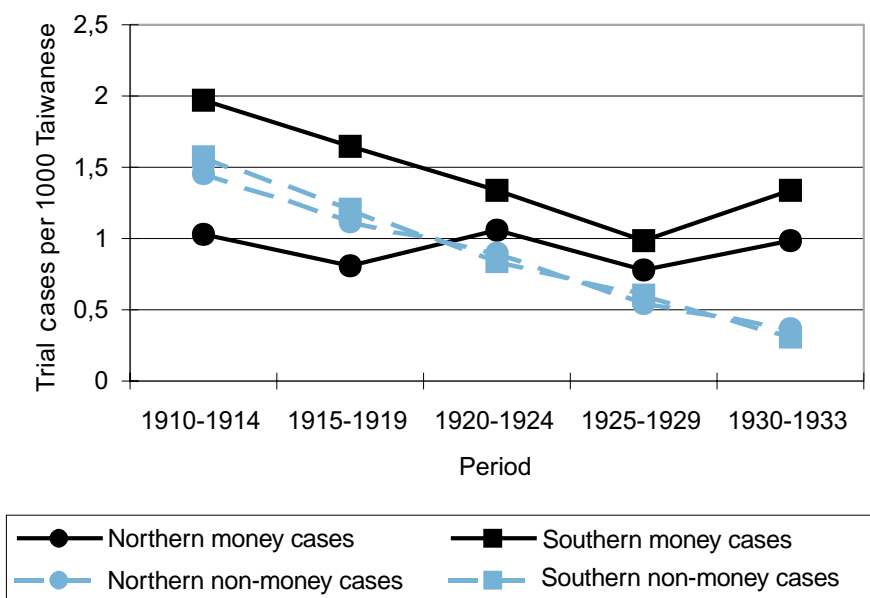

Note: Calculated from the "Cases Settled by Type in Civil Suits in Arbitration Courts” tables (民事爭訟調停種類別處理件數) in RESEARCH OFFICE, SECRETARIAT, TAIWAN GOVERNMENT-GENERAL [1905-1940, years 1910-1933].

The above evidence clearly points to a larger southern risk premium, but does not indicate the cause of the risk premium. The problem could be institutional or environmental. If southerners lived in a riskier environment, they might face a higher risk premium even while making use of the same institutions as northerners. For 
instance, they may have been more subject to crop failures or disabling diseases. ${ }^{5}$ As interest rates show, however, informal lenders were specialists in loans with relatively high risk. If the environmental risk were high in the south, then one would expect informal lenders to be most active in this region. In fact, as was shown in table four, formal institutions were more important in the south than in the north for all types of borrowers both in 1933 and in 1940. This strongly supports the hypothesis that the problem was institutional. Enforcement of loan contracts among individuals in the south was inferior to that in the north which allowed the newly introduced formal lending institutions to compete more effectively in the south.

\section{The Effect of the North-South Risk Premium Differential}

The relatively high-risk premium handicapped the south Taiwanese economy in three ways. First, it complicated property rights in land raising transaction costs. Second, it eventually led to a greater dependence on formal Japanese lending institutions which exacerbated the differences between rich and poor. Finally, it may have seriously hindered the development of irrigation.

In the traditional Taiwanese economy, landed farmers used two methods to borrow money: the $t^{\prime} a i$ (胎) loan and the tien (典) loan. When borrowing money using a t'ai loan, the borrower used his land or house deed as security for the loan. The deed was not returned until the loan was repaid. A lender who held such a deed, however, had no right to the debtor's property should the loan not be repaid unless otherwise specified in the contract. The deed itself was the collateral, not the property. Evicting a debtor from his land was an activity with which the government did not get involved. As a result, Japanese students of customary Taiwanese law reported that a $t$ 'ai loan was difficult to enforce and was only used among friends and for relatively small loans over short lengths of time. The value of a t'ai loan would usually be approximately $30 \%$ of the value of the property represented by the deed. The tien loan was a means of circumventing the limits of the t'ai loan. A tien loan required the debtor to give possession of his land or house to the lender at the time that the loan was made. A tien loan paid no interest. The lender instead got the right to the actual stream of income from the property. He could use the property himself or settle a tenant on the property. When the loan was eventually repaid, the property was returned. The problem with a tien loan was that it left property under the temporary control of a lender who had limited incentive to invest in the property since it would probably return to the debtor's control in the future. A temporary holder of a dry field, for instance, would not be interested in cooperating with neighbors to introduce irrigation into the area. Even if the borrower was many years late returning the loan, he could still reclaim the land upon repayment of the original

5 Actually, the south seems to have been no more subject to crop failures. The disease environment was worse, but I have not been able to link this or any other population or geographic characteristic with the interest rate premium using cross-sectional regressions. 
sum (OKAMATSU [1902, pp. 142-155]). WICKBERG [1970] made a study of twelve villages in northern Taiwan and judged that tien loans were not a serious problem in the north. He reports that around the turn-of-the-century only $6 \%$ of the land in the villages he studied was being held by people who had made tien loans. The situation, however, was different in the south.

From 1905 to 1920, Japanese registered $t$ 'ai and tien loans along with land sales and other land transfers. After 1920, there was a reform and these types of loans were replaced by modern collateralized loans. Table eight records the figures for t'ai and tien loans. Tien loans were much more popular in the south than in the north throughout this period.

Table 8

Ratio of Registered tien and t'ai Loans to Registered Sales, 1905-1920

\begin{tabular}{|c|c|c|c|c|c|c|c|c|}
\hline \multirow[b]{2}{*}{ Area } & \multicolumn{2}{|c|}{ 1905-1908 } & \multicolumn{2}{|c|}{ 1909-1912 } & \multicolumn{2}{|c|}{ 1913-1916 } & \multicolumn{2}{|c|}{$1917-1920$} \\
\hline & $\begin{array}{l}\text { tien } \\
\text { loans }\end{array}$ & $\begin{array}{l}t^{\prime} a i \\
\text { loans }\end{array}$ & $\begin{array}{l}\text { tien } \\
\text { loans }\end{array}$ & $\begin{array}{l}t^{\prime} a i \\
\text { loans }\end{array}$ & $\begin{array}{l}\text { tien } \\
\text { loans }\end{array}$ & $\begin{array}{l}t^{\prime} a i \\
\text { loans }\end{array}$ & $\begin{array}{l}\text { tien } \\
\text { loans }\end{array}$ & $\begin{array}{l}t^{\prime} a i \\
\text { loans }\end{array}$ \\
\hline Taipei & $\begin{array}{l}0.32 \\
(2795)\end{array}$ & $\begin{array}{l}1.07 \\
(9387)\end{array}$ & $\begin{array}{l}0.06 \\
(939)\end{array}$ & $\begin{array}{l}0.82 \\
(12572)\end{array}$ & $\begin{array}{l}0.04 \\
(651)\end{array}$ & $\begin{array}{l}0.90 \\
(16213)\end{array}$ & $\begin{array}{l}0.02 \\
(312)\end{array}$ & $\begin{array}{l}0.70 \\
(14528)\end{array}$ \\
\hline Hsinchu & $\begin{array}{l}0.11 \\
(863)\end{array}$ & $\begin{array}{l}0.73 \\
(5568)\end{array}$ & $\begin{array}{l}0.03 \\
(443)\end{array}$ & $\begin{array}{l}0.55 \\
(9286)\end{array}$ & $\begin{array}{l}0.02 \\
(348)\end{array}$ & $\begin{array}{l}0.56 \\
(11588)\end{array}$ & $\begin{array}{l}0.01 \\
(225)\end{array}$ & $\begin{array}{l}0.58 \\
(14397)\end{array}$ \\
\hline $\begin{array}{l}\text { Tai- } \\
\text { chung }\end{array}$ & $\begin{array}{l}0.45 \\
(7718)\end{array}$ & $\begin{array}{l}0.31 \\
(5380)\end{array}$ & $\begin{array}{l}0.06 \\
(2023)\end{array}$ & $\begin{array}{l}0.35 \\
(10948)\end{array}$ & $\begin{array}{l}0.04 \\
(1317)\end{array}$ & $\begin{array}{l}0.43 \\
(14428)\end{array}$ & $\begin{array}{l}0.01 \\
(481)\end{array}$ & $\begin{array}{l}0.36 \\
(14913)\end{array}$ \\
\hline North & $\begin{array}{l}0.35 \\
(11021)\end{array}$ & $\begin{array}{l}0.58 \\
(18109)\end{array}$ & $\begin{array}{l}0.06 \\
(3317)\end{array}$ & $\begin{array}{l}0.51 \\
(29796)\end{array}$ & $\begin{array}{l}0.03 \\
(2251)\end{array}$ & $\begin{array}{l}0.57 \\
(38460)\end{array}$ & $\begin{array}{l}0.01 \\
(979)\end{array}$ & $\begin{array}{l}0.50 \\
(40754)\end{array}$ \\
\hline Tainan & $\begin{array}{l}1.03 \\
(33914)\end{array}$ & $\begin{array}{l}0.10 \\
(3169)\end{array}$ & $\begin{array}{l}0.12 \\
(9073)\end{array}$ & $\begin{array}{l}0.12 \\
(9248)\end{array}$ & $\begin{array}{l}0.10 \\
(7748)\end{array}$ & $\begin{array}{l}0.34 \\
(25265)\end{array}$ & $\begin{array}{l}0.04 \\
(3757)\end{array}$ & $\begin{array}{l}0.36 \\
(30822)\end{array}$ \\
\hline $\begin{array}{l}\text { Kaoh- } \\
\text { siung }\end{array}$ & $\begin{array}{l}0.81 \\
(8527)\end{array}$ & $\begin{array}{l}0.11 \\
(1124)\end{array}$ & $\begin{array}{l}0.09 \\
(2743)\end{array}$ & $\begin{array}{l}0.07 \\
(2256)\end{array}$ & $\begin{array}{l}0.06 \\
(1804)\end{array}$ & $\begin{array}{l}0.29 \\
(8898)\end{array}$ & $\begin{array}{l}0.02 \\
(719)\end{array}$ & $\begin{array}{l}0.31 \\
(9256)\end{array}$ \\
\hline South & $\begin{array}{l}0.98 \\
(42441)\end{array}$ & $\begin{array}{l}0.10 \\
(4293)\end{array}$ & $\begin{array}{l}0.11 \\
(11816)\end{array}$ & $\begin{array}{l}0.11 \\
(11504)\end{array}$ & $\begin{array}{l}0.09 \\
(9552)\end{array}$ & $\begin{array}{l}0.33 \\
(34163)\end{array}$ & $\begin{array}{l}0.04 \\
(4476)\end{array}$ & $\begin{array}{l}0.35 \\
(40078)\end{array}$ \\
\hline
\end{tabular}

Note: Figures in parentheses are total registered tien and t'ai loans in the area. Figures taken from the land registration tables in RESEARCH OFFICE, SECRETARIAT, TAIWAN GOVERNMENT-GENERAL [1905-1940, years 1905-1920].

In southern courts, from 1905 to 1908 , there were 0.98 tien contracts per land sale while in the north there were only 0.35 tien contracts. ${ }^{6}$ In the north, the $t^{\prime}$ ai form

\footnotetext{
6 The comparison is made with land sales contracts because I do not have population or land area statistics for court districts. Generally, there were more land sales registered per person in the south, so southern figures would be higher with respect to population.
} 
of loan was much more likely to be used. In the 1905-1908 period, there were 0.58 $t$ 'ai contracts per land sale registered in the north and only 0.10 in the south. The use of the $t^{\prime}$ ai in the north and the tien in the south reflects the relative efficiency of northern informal institutions. In the north, it appears that the weaker $t$ 'ai loan could be enforced often enough that it was a standard tool when borrowing money. Farmers only needed to resort to the tien loan infrequently. To get a rough estimate of how much the tien loan may have affected southern property one could multiply WICKBERG's [1970] 6\% figure for land affected in the north by 3.4 to arrive at a rough estimate of $20 \%$ of land held through a tien in the south. ${ }^{7}$ The statistics show that the use of the tien fell throughout Taiwan in this period as Japanese now offered formal enforcement services for other loan forms. In the south, the $t^{\prime} a i$ loan form quickly grew in popularity after 1912. This is evidence that not only were risk premiums falling due to the growth of formal lending institutions but also due to the formal legal enforcement of loans between neighbors, friends and relatives. However, since formal enforcement practices were the same in the north and south, the risk premium differential seems to be a product of differences in informal enforcement practices among the Taiwanese population.

The early Japanese investigation into Taiwanese customary law also shows that tien were more often used in the south and $t$ ' $a i$ in the north. In doing this investigation the Japanese collected 58 t'ai and 62 tien contracts dating from 1783 to 1907 but mainly clustered in the late nineteenth century. These were published as part of an appendix to the investigation (COMMISSION FOR THE INVESTIGATION OF OLD LAWS IN FormosA [1911, Vol. I, Sec. II, pp. 124-249]). Of the $t$ 'ai contracts, 32 can be identified as being from the north and 21 from the south. Of the tien contracts, 18 can be identified as northern and 33 as southern.

After the Japanese took control of the island, the formal credit sector described in the previous section of this paper came into existence. It was an important source of relatively cheap credit, particularly to those who had collateral. The formal sector relied more heavily on formal means of enforcing loan repayments and interest payments and so it was not as strongly affected by north-south differences. The formal lending sector became most important in the south since the informal sector there charged much higher interest rates. As shown in table five, by 1933, formal institutions accounted for $56.1 \%$ of the money loaned to landed farmers in the south but only $41.6 \%$ in the north. Northern tenants were also less likely to borrow from formal institutions. The 1940 statistics show that virtually all the money borrowed by southern landlords came from formal institutions while in the north, landlords chose to borrow almost half the money they needed from individuals. The introduction of formal lending to the island thus helped southern agriculture more than northern agriculture. But since the formal sector was primarily used by landed farmers, it was primarily landed southern farmers who benefited since the informal sector remained

7 I arrive at the 3.4 figure by dividing the 1905-1908 tien/sales contract ratio for the total south, 0.98, by the ratio for the area Wickberg studied, Taipei (not including the Ilan area) and Taoyuan (northern Hsinchu prefecture), 0.29. 
more important for tenant farmers. Table three shows that the average interest rate facing tenant farmers in the north in 1933 was only $1.4 \%$ higher than the average rate faced by landed farmers while in the south the difference was 3.2\%. By 1940, formal institutions had become more accessible to tenant farmers, but the interest rate gap was still wider in the south: $0.9 \%$ versus $1.8 \%$.

Besides land, the most important non-human input into Taiwanese agriculture was irrigation. Before the Japanese takeover of Taiwan, irrigation was much more prevalent in the north than the south. By the end of the Japanese era, irrigation was as common in the south as in the north (see table nine). A common explanation for the shift in the irrigation pattern is technological. The most important irrigation project of the Japanese era was the huge Jianan irrigation project (亮南大圳) that covered a large portion of the south and involved some impressive feats of engineering. The impression has thus been created that southern irrigation came later because it was technically more difficult and required more capital and larger scale.

Table 9

Percentage of Farmland Irrigated, North and South, 1905-1940

\begin{tabular}{llllllll}
\hline \multirow{2}{*}{ Year } & \multicolumn{7}{c}{ Area } \\
\cline { 2 - 8 } & Taipei & Hsinchu & Taichung & $\begin{array}{l}\text { Northern } \\
\text { average }\end{array}$ & Tainan & $\begin{array}{l}\text { Kaoh- } \\
\text { siung }\end{array}$ & $\begin{array}{l}\text { Southern } \\
\text { average }\end{array}$ \\
\hline & & & & & & & \\
\hline 1905 & $46.8 \%$ & $50.8 \%$ & $52.8 \%$ & $50.6 \%$ & $12.1 \%$ & $27.5 \%$ & $16.9 \%$ \\
1910 & $54.2 \%$ & $51.3 \%$ & $54.3 \%$ & $53.2 \%$ & $14.5 \%$ & $31.0 \%$ & $19.7 \%$ \\
1915 & $52.6 \%$ & $50.9 \%$ & $59.4 \%$ & $54.6 \%$ & n.d. & n.d. & $22.5 \%$ \\
1920 & $48.9 \%$ & $50.9 \%$ & $58.9 \%$ & $53.5 \%$ & $19.7 \%$ & $43.1 \%$ & $27.5 \%$ \\
1925 & $50.0 \%$ & $46.1 \%$ & $57.1 \%$ & $51.4 \%$ & $39.4 \%$ & $44.6 \%$ & $41.1 \%$ \\
1930 & $46.9 \%$ & $49.8 \%$ & $63.6 \%$ & $54.4 \%$ & $70.1 \%$ & $49.3 \%$ & $63.2 \%$ \\
1935 & $46.9 \%$ & $49.5 \%$ & $61.8 \%$ & $53.9 \%$ & $70.5 \%$ & $54.9 \%$ & $65.3 \%$ \\
1940 & $48.0 \%$ & $60.2 \%$ & $72.9 \%$ & $62.6 \%$ & $68.9 \%$ & $61.3 \%$ & $66.4 \%$ \\
\hline
\end{tabular}

Note: Calculated from Research Office, Secretariat, Taiwan GovernmentGENERAL [1905-1940]. Due to the manner in which the political boundaries were drawn the southern area could not be divided into two regions from 1910 to 1920. To estimate the percentage of fields irrigated in each area in 1910, I assumed that the ratio of southern irrigation in Tainan and Kaohsiung in 1910 was the same as in 1909. For 1920, I used the 1921 ratio. To calculate percentages, land in irrigation projects is compared with total taxable farmland. A small amount of farmland was not taxed.

This paper, however, provides a second hypothesis: irrigation came later to the south because the large risk premium (1) made it more costly to pool large quantities of capital and (2) encouraged tien loans which separated ownership and control of land. It was, at least in part, the introduction of formal Japanese lending institutions 
and formal methods of contract enforcement that allowed the south to catch up with the north in irrigation. Banks began lending to irrigation projects in 1904 and, by 1911, 39 of the 63 large irrigation projects (defined as those over 600 chia or roughly 1500 acres in area) had loans outstanding, generally at rates of about $8 \%$ to 9\% (OFFice of Civil EngineERing, Division of Civil AfFairs, TAIWAN GOVERNMENT-GENERAL [1912]). The technological explanation of southern backwardness in irrigation is probably true in part, but the pattern of irrigation growth in the south suggests that the introduction of formal Japanese institutions was also important. The Jianan irrigation system in Tainan prefecture came into service in the early 1920s. But table nine shows that growth in irrigated land began well before this in Tainan. The large growth in irrigated land after 1920 in Tainan can be attributed to the Jianan irrigation system and may not have been possible without modern technology. South of Tainan, Kaohsiung prefecture was not affected by the Jianan project but it also quickly caught up with the north in the proportion of its farmland that was irrigated.

\section{Conclusions}

A risk premium directly hampers growth by interfering with the free flow of capital within an economy. It may also signal an underlying lack of cooperation among individuals in the economy which could raise transaction costs generally. The evidence clearly suggests that the risk premium in informal capital markets was higher in southern Taiwan than in northern Taiwan in the 1930s. This interest rate gap probably extended back to the early period of Japanese rule and perhaps back into the Ch'ing dynasty. The gap remained during the early period of KMT rule. Interestingly, the small and medium export-oriented businesses, so important to the post-war "Taiwanese miracle" were primarily centered in the northern low interest rate areas. These businesses relied heavily on informal credit markets for venture capital. However, more work needs to be done, and is being done, before a causal relationship can be asserted.

The risk premium handicapped the southern economy until formal Japanese institutions became important sources of loans in Taiwan. The new formal lending institutions largely solved the risk premium problem faced by landed farmers, but non-landed farmers had limited recourse to such institutions. After the war, formal lending institutions were only slowly reestablished by the KMT and both landed and non-landed farmers once again had to depend on the informal loan market.

Finally, one should note that even in the south, interest rates in the informal credit markets of Taiwan were relatively low. The Survey of Interest Rates shows that while southern Taiwanese informal interest rates were higher than those in Japan, ${ }^{8}$ they were lower than those faced by overseas Japanese and much lower than those in Korea (TAX OfFICE, Finance Bureau, TAIWAN Government-GENERAL [1936]). Taiwanese informal interest rates were also lower than those found any-

${ }^{8}$ Informal interest rates in northern Taiwan were very comparable to those in Japan. 
where in China (BUCK [1937, p. 462]). The southern Taiwanese risk premium was not particularly high. It was the northern Taiwan risk premium that was particularly low.

\section{References}

Agriculture Office, Agriculture and Industry Bureau, Taiwan GovernmentGENERAL (臺灣總督府殖座局農務課) [1930a], Basic Agricultural Survey, Vol. XXV: First Survey of Land Rents (農業基本調杳曺第一十五本 妌地賃貸經濟調查 其 , 一), Taipei (in Japanese).

- - [1930b], Basic Agricultural Survey, Vol. XXVI: Second Survey of Land Rents (農業基本 調查書第二十六本 耕地賃貸經濟調查 其 二,), Taipei (in Japanese).

- - [1935], Basic Agricultural Survey, Vol. XXXIII: Survey of Agricultural Financing (農業基 本調查書第三十二本農業金融調查), Taipei (in Japanese).

- - [1940], Basic Agricultural Survey, Vol. XLIII: Survey of Agricultural Financing (農業基 本調查青第四十二本農業金融調查), Taipei (in Japanese).

A'Hearn, B. [2000], "Could Southern Italians Cooperate? Banche Popolari in the Mezzogiorno," Journal of Economic History, 60, 67-93.

BuCK, J. [1937], Land Utilization in China, University of Chicago Press: Chicago.

CH'ENG, C. Y. (程家穎) [1914/1963], Report on the Land System in Taiwan (臺灣土 地制度考察報告書), Bank of Taiwan: Taipei (in Chinese).

COMMISSION FOR THE INVESTIGATION OF OLD LAWS AND CUSTOMS IN FORMOSA (臨時臺灣舊慣調查會) [1911], Appendix to the Taiwanese Common Law Report (萦灣私法附錄參考書), Tokyo (in Chinese and Japanese).

DAVIDSON, J. W. [1903/1992], The Island of Formosa Past and Present, SMC Publishing Inc.: Taipei.

DePartment of Agriculture and Forestry, Taiwan PROVInCial Government (臺灣省政府農林廳) [1950], Report of Investigation of Agricultural Finance (譨業金融調查報告書), Taipei (in Chinese).

DE SoTO, H. [1989], The Other Path: The Invisible Revolution in the Third World, Harper and Row: New York.

ECONOMic Research Section, CENTRAL BANK OF China (中央銀行經濟研究處) [1964], The Republic of China Taiwan Financial Statistics Monthly（中華民國臺灣金融 統計月報), Taipei (in Chinese).

GREIF, A. [1994], "Cultural Beliefs and the Organization of Society: A Historical and Theoretical Reflection on Collectivist and Individualistic Societies," Journal of Political Economy, 102, 912-950.

- - [1997], "Contracting, Enforcement, and Efficiency: Economics beyond the Law," pp. 239-265 in: M. Bruno and B. Pleskovic (eds.), Annual World Bank Conference on Development Economics 1996, The World Bank: Washington, DC.

Hsu, W. H. [1980], “Frontier Social Organization and Social Disorder in Ch'ing Taiwan,” pp. 87-106 in: R. Knapp (ed.), China's Island Frontier: Studies in the Historical Geography of Taiwan, University Press of Hawaii: Honolulu.

Hsu, Y. A., C. PANNell, AND J. Wheeler [1980], "The Development and Structure of Transportation Networks in Taiwan: 1600-1972," pp. 167-201 in: R. Knapp (ed.), China's Island Frontier: Studies in the Historical Geography of Taiwan, University Press of Hawaii: Honolulu.

KNAPP, R. [1999], “The Shaping of Taiwan's Landscape,” pp. 3-26 in: M. Rubinstein (ed.), Taiwan: A New History, M. E. Sharpe: Armonk, NY.

Moser, M. [1982], Law and Social Change in a Chinese Community, Oceana Publications: Dobbs Ferry, NY. 
NoRTH, D. [1990], Institutions, Institutional Change and Economic Performance, Cambridge University Press: Cambridge.

OfFice of Civil Engineering, Division of Civil AfFairs, TAiwan GovernmentGENERAL (臺灣總督府民政部土木句) [1912], Taiwan Irrigation Project Statistics 1911 (辜灣埤圳統动), Taipei (in Japanese).

Okamatsu, S. [1902], Provisional Report on Investigations of Laws and Customs in the Island of Formosa, Kobe Herald: Kobe.

OLDS, K. [2002], "The Biological Standard of Living in Taiwan under Japanese Occupation," Social Science History, forthcoming.

- - AND R.-H. LIU [2000], "Economic Cooperation in 19th-Century Taiwan: Religion and Informal Enforcement," Journal of Institutional and Theoretical Economics, 156, 404430.

PROVISIONAL TAIWAN LAND SuRVEY OFFICE (臨時臺灣土地調査局) [1906a], A Survey of Paddy Sale Prices and Interest Rates (田買賣價格及金利調查書), Taipei (in Japanese). ${ }^{9}$

- - [1906b], A Survey of Dry Field Sale Prices and Interest Rates (買賣價格父金利調 查書), Taipei (in Japanese). ${ }^{9}$

Putnam, R. [1993], Making Democracy Work: Civic Traditions in Modern Italy, Princeton University Press: Princeton.

RESEARCH OFFICE, SECRETARIAT, TAIWAN GOVERNMENT-GENERAL (臺灣總督府官房調 查課) [1905-1940], Taiwan Government-General's Statistical Annual (臺灣總督府統 計書), Taipei (in Japanese).

SANITATION OFFICE, INTERIOR BUREAU, TAIWAN GOVERNMENT-GENERAL (臺灣總督府 警務局衛生課) [1926], Sanitation Survey (衛生調查書), Vol. V: Taiwanese Causeof-Death Statistics (臺灣死因統計), Taipei (in Japanese).

TAI, Y. H. (戴炎輝) [1979], Local Government in Ch'ing-Dynasty Taiwan (清代臺灣之 鄉治), Lien Ching Publishers: Taipei.

TAX OFFICE, FinANCE BuREAU, TAIWAN GOVERNMENT-GENERAL (臺灣總督府财務局 税務課) [1936], An Investigation of Interest Rates (金利調查書), Taipei (in Japanese).

WiCKBERG, E. [1970], "Late Nineteenth Century Land Tenure in North Taiwan,” pp. 78-92 in: L. Gordon (ed.), Taiwan: Studies in Chinese Local History, Columbia University Press: New York-London.

WinN, J. K. [1994], "Relational Practices and the Marginalization of Law: Informal Financial Practices of Small Businesses in Taiwan," Law and Society Review, 28, 193-232.

Kelly B. Olds

Department of Economics

National Taiwan University

No. 21, Hsu Chow Rd.

Taipei, Taiwan 100

R.O.C.

E-mail: olds@ms.cc.ntu.edu.tw

9 This book is originally undated. The study recorded was most probably done at about 1906 (plus or minus one year). 